\title{
Correction to: Species disparity response to mutagenesis of marine yeasts for the potential production of biodiesel
}

\author{
Boutheina Bessadok ${ }^{1,2}$, Andrea Santulli ${ }^{3}$, Thomas Brück ${ }^{4}$ and Saloua Sadok ${ }^{1 *}$ (1)
}

\section{Correction to: Biotechnol Biofuels (2019) 12:129 https://doi.org/10.1186/s13068-019-1459-y}

The original version of the article [1] unfortunately contained a mistake in author's second name. The name of the author has been corrected from Thomas Breuck to Thomas Brück in this correction article. The original article has been corrected.

\section{Reference}

1. Bessadok B, Santulli A, Brück T, Sadok S. Species disparity response to mutagenesis of marine yeasts for the potential production of biodiesel. Biotechnol Biofuels. 2019;12:129. https://doi.org/10.1186/s1306 8-019-1459-y.

\section{Publisher's Note}

Springer Nature remains neutral with regard to jurisdictional claims in published maps and institutional affiliations.

\begin{abstract}
Author details
1 Blue Biotechnology and Aquatics Bioproducts Laboratory (B3Aqua), Institut National des Sciences et Technologies de la Mer - INSTM-Annexe La Goulette, 60 Port de Pêche, 2060 La Goulette, Tunisia. ${ }^{2}$ Institut National Agronomique de Tunisie (INAT), 43 Avenue Charles Nicolle, 1082 Tunis, Tunisia. ${ }^{3}$ Consorzio Universitario della Provincia di Trapani (CUPT), Lungomare Dante Alighieri, 91016 Casa Santa, TP, Italy. ${ }^{4}$ Fachgebiet Industrielle Biokatalyse, IBK Technische Universität München, Lichtenbergstraße 4, 85748 Garching, Germany.
\end{abstract}

The original article can be found online at https://doi.org/10.1186/s1306 8-019-1459-y.

Received: 11 January 2019 Accepted: 2 May 2019

Published online: 20 June 2019
*Correspondence: salwa.sadok@instm.rnrt.tn

${ }^{1}$ Blue Biotechnology and Aquatics Bioproducts Laboratory (B3Aqua), Institut National des Sciences et Technologies de la Mer - INSTM-Annexe

La Goulette, 60 Port de Pêche, 2060 La Goulette, Tunisia

Full list of author information is available at the end of the article (c) The Author(s) 2019. This article is distributed under the terms of the Creative Commons Attribution 4.0 International License (http://creativecommons.org/licenses/by/4.0/), which permits unrestricted use, distribution, and reproduction in any medium, provided you give appropriate credit to the original author(s) and the source, provide a link to the Creative Commons license, and indicate if changes were made. The Creative Commons Public Domain Dedication waiver (http://creativecommons.org/ publicdomain/zero/1.0/) applies to the data made available in this article, unless otherwise stated. 